\title{
The decapod fauna (Axiidea, Anomura, Brachyura) from the Late Pleistocene of Trumbacà, Reggio Calabria (Calabria, southern Italy)
}

\author{
Alessandro Garassino ${ }^{1 *}$, Giovanni Pasini², Antonio De Angeli³, Matúš Hyžný ${ }^{4}$
}

\begin{abstract}
We report a rich faunal assemblage from the Tyrrhenian (Late Pleistocene) of Trumbacà, located in the southern area of Reggio Calabria (Calabria, southern Italy). The only brachyuran reported to date from this locality is Ranilia constricta (A. Milne Edwards, 1880) by Vazzana (2008). The studied specimens have been assigned, as follows: ?Corallianassa sp., Dardanus arrosor (Herbst, 1796), Dardanus substriatus (A. Milne Edwards, 1861), Paguristes $\mathrm{cf}$. P. syrtensis de Saint Laurent 1970, Anapagurus sp., Ranilia constricta (A. Milne Edwards, 1880), Ranina propinqua Ristori, 1891, Ebalia $\mathrm{cf}$. E. deshayesi Lucas, 1846, Ilia nucleus (Linnaeus, 1758), Medorippe lanata (Linnaeus, 1767), Calappa granulata (Linnaeus, 1758), Pisa armata (Latreille, 1803), Derilambrus cf. D. angulifrons (Latreille, 1825), Atelecyclus undecimdentatus (Herbst, 1783), Carcinus sp., Pilumnus hirtellus (Linnaeus, 1761), and Xantho cf. X. incisus (Leach, 1814). The studied assemblage enlarges our knowledge on the evolution of the Mediterranean decapod faunas.
\end{abstract}

Key-words: Decapoda, Axiidea, Anomura, Brachyura, Late Pleistocene, Calabria, southern Italy.

Riassunto - La fauna a crostacei decapodi (Axiidea, Anomura, Brachyura) del Pleistocene superiore di Trumbacà, Reggio Calabria (Calabria, Italia meridionale).

Viene descritta una ricca associazione a crostacei decapodi del Tirreniano (Pleistocene superiore) di Trumbacà, località ubicata a sud di Reggio Calabria (Calabria, Italia meridionale). L'unico crostaceo decapode descritto da questa località é Ranilia constricta (A. Milne

${ }^{1}$ Sezione di Paleontologia degli Invertebrati, Museo di Storia Naturale, Corso Venezia 55, 20121 Milano, Italia

${ }^{2}$ Via Alessandro Volta 16, 22070 Appiano Gentile (Como), Italia E-mail: juanaldopasini@tiscali.it

Museo Civico Zannato, Piazza Marconi 15, 36075 Montecchio Maggiore (Vicenza), Italia E-mail: antonio.deangeli@alice.it

${ }^{4}$ Geologisch-paläontologische Abteilung, Naturhistorisches Museum Wien, Burgring 7, 1010 Vienna, Austria Department of Geology and Paleontology, Faculty of Natural Sciences, Comenius University, Mlynská dolina G1, 84215 Bratislava, Slovakia

E-mail: hyzny.matus@gmail.com

* Corresponding author: alessandro.garassino@comune.milano.it; alegarassino@gmail.com

(C) 2014 Alessandro Garassino, Giovanni Pasini, Antonio De Angeli \& Matúš Hyžný

Received: $4^{\text {th }}$ June 2014

Accepted for publication: $4^{\text {th }}$ November 2014
Edwards, 1880), segnalata da Vazzana (2008). Gli esemplari oggetto di questo studio sono stati così assegnati: ?Corallianassa sp., Dardanus arrosor (Herbst, 1796), Dardanus substriatus (A. Milne Edwards, 1861), Paguristes cf. P. syrtensis de Saint Laurent 1970, Anapagurus sp., Ranilia constricta (A. Milne Edwards, 1880), Ranina propinqua Ristori, 1891, Ebalia cf. E. deshayesi Lucas, 1846, Ilia nucleus (Linnaeus, 1758), Medorippe lanata (Linnaeus, 1767), Calappa granulata (Linnaeus, 1758), Pisa armata (Latreille, 1803), Derilambrus cf. D. angulifrons (Latreille, 1825), Atelecyclus undecimdentatus (Herbst, 1783), Carcinus sp., Pilumnus hirtellus (Linnaeus, 1761), and Xantho cf. X. incisus (Leach, 1814). L'associazione descritta incrementa le nostre conoscenze sull'evoluzione delle faune a crostacei decapodi del Mediterraneo.

Parole chiave: Decapoda, Axiidea, Anomura, Brachyura, Pleistocene superiore, Calabria, Italia meridionale.

\section{INTRODUCTION}

The studied specimens were collected from a grey, micaceous, thin sandy deposists from the Tyrrhenian (Late Pleistocene) of Trumbacà district, located at southeastearn of Reggio Calabria (Calabria, southern Italy, $\left.38^{\circ} 6^{\prime} 52.66^{\prime \prime} \mathrm{N} 15^{\circ} 39^{\prime} 0.73^{\prime \prime} \mathrm{E}\right)$. Trumbacà is nearby (about two hundred meters) the coeval Bovetto district, from which Garassino \& De Angeli (2008) previously reported Ranilia constricta (A. Milne Edwards, 1880). Moreover, Garassino et al. (2010b) also reported Homola barbata (Fabricius, 1793), from the Cafari district (Reggio Calabria), one of the several fossiliferous localities (close each other) collected from the Late Pleistocene arenaceous series cropping out in the southern area of Reggio Calabria (Bovetto, Trumbacà, Cafari, Ravagnese, among others). A natural exposure (about $5 \mathrm{~m}$ thick) and 100 meters above sea level, crosses and exposes the Late Pleistocene fossiliferous sandy bench series in Trumbacà district. This locality was previously known for its rich and well-preserved typical Tyrrhenian malacofauna (Bonfiglio, 1972). The only brachyuran reported to date from this locality is Ranilia constricta (Vazzana, 2008). A rich sample of axiideans, anomurans, and brachyurans enlarge the knowledge of decapod communities from the Late Pleistocene (Tyrrhenian) of the Mediterranean area.

\section{MATERIALS}

The studied sample includes 46 specimens of axiideans, anomurans and brachyurans. The infraorder Axiidea de Saint Laurent, 1979, includes ?Corallianassa sp. 
(2 specimens) (Callianassidae Dana, 1852); the infraorder Anomura H. Milne Edwards, 1832, includes Dardanus arrosor (Herbst, 1796) (2 specimens), D. substriatus (A. Milne Edwards, 1861) (3 specimens), Paguristes cf. P. syrtensis de Saint Laurent, 1970 (1 specimen) (Diogenidae Ortmann, 1892), and Anapagurus sp. (3 specimens) (Paguridae Latreille, 1802); the infraorder Brachyura Latreille, 1802, includes Ranilia constricta (A. Milne Edwards, 1880) (6 specimens), Ranina propinqua Ristori, 1891 (1 specimen) (Raninidae De Haan, 1839), Ebalia cf. E. deshayesi Lucas, 1846 (1 specimen), Ilia nucleus (Linnaeus, 1758) (1 specimen) (Leucosiidae Samouelle, 1819), Medorippe lanata (Linnaeus, 1767) (1 specimen) (Dorippidae MacLeay, 1838), Calappa granulata (Linnaeus, 1758) (9 specimens), Pisa armata (Latreille, 1803) (3 specimens) (Pisidae Dana, 1851), Derilambrus cf. $D$. angulifrons (Latreille, 1825) (2 specimens) (Parthenopidae MacLeay, 1838), Atelecyclus undecimdentatus (Herbst, 1783) (1 specimen) (Atelecyclidae Ortmann, 1893), Carcinus sp. (2 specimens) (Portunidae Rafinesque, 1815), Pilumnus hirtellus (Linnaeus, 1761) (5 specimens) (Pilumnidae Samouelle, 1819), and Xantho cf. X. incisus (Leach, 1814) (3 specimens) (Xanthidae MacLeay, 1839). Due to the very delicate nature of the fossils and the loose matrix, all specimens were fixed with a film of polyvinyl acetate for study and preservation. The specimens are housed in the palaeontological collections of the Museo di Storia Naturale di Milano (MSNM).

For the higher-level classification, we follow the recent arrangement proposed by Ng et al. (2008), De Grave et al. (2009), and Van Bakel et al. (2012).

\section{Abbreviations}

hc: height of the carpus; hpa: height of the palm; lc: length of the carpus; lcxp: length of the carapace (excluding rostrum); ld: length of the dactylus; li: length of the index; lpa: length of the palm; wcxp: width of the carapace.

\section{SYSTEMATIC PALAEONTOLOGY}

Order Decapoda Latreille, 1803

Infraorder Axiidea de Saint Laurent, 1979

Family Callianassidae Dana, 1852

Subfamily Callichirinae Manning \& Felder, 1991

Genus Corallianassa Manning, 1987

Type species: Callianassa longiventris A. Milne Edwards, 1870 by original designation.

Included fossil species: Corallianassa acucurvata Swen, Fraaije \& van der Zwaan, 2001.

Discussion. In Corallianassa major merus is ovoid, with armed lower margin, either with denticles (e.g. in $C$. articulata Rathbun, 1906; see Rathbun, 1906: fig. 47b and Sakai, 1999: fig. 15d, e) or large spines (e.g. in C. longiventris (A. Milne Edwards, 1870); see Borradaile, 1904: fig. 2b). In this respect, it is similar to Glypturus Stimpson, 1866 (Hyžný \& Müller, 2012). With the exception of one species, Corallianassa intesi (de Saint Laurent \& Le Lo- euff, 1979), the lower margin of carpus does not possess spines which is typical for Glypturus. Numerous extant species of Corallianassa possess major propodus that are highest around the midpoint, thus having a convex upper margin (see e.g. Rathbun, 1906: fig. 47b; Poore \& Griffin, 1979: fig. 26c; Dworschak, 1992: fig. 14a; Sakai, 1999: fig. 16d, 18c). This is not usual for other callianassid genera, although one can observe variation in this character. Corallianassa usually has a rather long dactylus both in major and minor chela. In the major one, it may be nearly as long as the propodus (e.g. Sakai, 1967: fig. 3C; Sakai, 1999: fig. 16d). Many species possess large setal pores at both fingers, sometimes extending on the palm. Major dactylus is robust, curved and without prominent teeth.

Corrallianassa acucurvata described by Swen et al. (2001) from the Maastrichtian of the Netherlands is based on specimens without merus (which is considered taxonomically important, see Manning \& Felder, 1991); other characters, however, conforms with the concept of Corallianassa as presented above.

Corallianassa rigoi described by De Angeli \& Garassino (2006b) from the Cretaceous of Italy exhibits a long major propodus with upper and lower margins parallel to each other, and with short fingers. This character combination is not typical for Corallianassa. Moreover, C. rigoi possesses an elongate carpus, triangular in outline, which is quite untypical for the genus. No convincing arguments for generic assignment were presented by De Angeli \& Garassino (2006b), and we remove the species from $\mathrm{Co}$ rallianassa. Re-examination of the type material is needed to resolve the generic status of C. rigoi.

?Corallianassa sp.

Fig. 1A

Material and measurements: One right major propodus (MSNM i27900 - hpa: $8 \mathrm{~mm}$; li: $5 \mathrm{~mm}$; lpa: $9 \mathrm{~mm}$ ); one left major dactylus (MSNM i27910 - ld: 9 mm).

Description: Major propodus slightly longer than high, highest around the midpoint, upper margin convex, lower margin rimmed; index relatively long, slightly shorter than palm; a faint ridge extends along the index and continues onto palm; outer lateral surface of palm covered with large setal pores at the base of the index; index stout, with blunt tip and a blunt tooth at the middle of the occlusal margin. Major dactylus massive and stout, upper margin forms distinct keel, occlusal margin unarmed, tip hooked; large setal pores forming rows extend along outer lateral surface close to the occlusal margin and along inner lateral surface close to the upper margin.

Discussion. The studied specimens show a suite of characters pointing to their generic identity. The propodus has a convex upper margin, its lower margin is rimmed, fingers possess large setal pores, the index is robust, relatively long and has a blunt tooth at its occlusal margin, dactylus is massive and its tip is hooked. Although none of these characters alone can be treated as diagnostic, their combination is quite typical for Corallianassa. In this respect, the studied material shows striking similarities to C. longiventris (see Borradaile, 1904: fig. 2b) and C. martensi (see Sakai, 1984: fig. 3B). The presence of 
the faint ridge on the dactylus, however, is unusual for the genus. Therefore, we treat the studied material with question mark.

Another possible candidate for the studied material would be Pestarella Ngoc-Ho, 2003. This taxon has not such prominent setal pores on the lateral surface of propodus like Corallianassa. Finally we point out that, if this studied material represents Corallianassa, it would be the first record for this genus in the fossil and extant record from the Mediterranean basin.

Infraorder Anomura MacLeay, 1838

Superfamily Paguroidea Latreille, 1802

Family Diogenidae Ortmann, 1892

Genus Dardanus Paul'son, 1875

Type species: Dardanus hellerii Paul'son, 1875, by monotypy.

Included fossil species: see Schweitzer et al. (2010: $53,54)$.

Dardanus arrosor (Herbst, 1796)

Fig. 1B

Material and measurements: 2 right propodi (MSNM i27885 - hpa: $11 \mathrm{~mm}$; li: $4 \mathrm{~mm}$; lpa: $16 \mathrm{~mm}$; MSNM i2 7887 - hpa: $9 \mathrm{~mm}$; li: $3 \mathrm{~mm}$; lpa: $14 \mathrm{~mm}$ ).

Description: Palm longer than high, with upper and lower margin almost parallel; palm covered with sinuous transverse crests, dentate anteriorly; triangular index, relatively long, with dentate transverse crests; occlusal margin with some weak teeth.

Discussion. The studied propodi show the typical morphological characters of the extant Dardanus arrosor (Herbst, 1796), widespread along the Atlantic coastlines (Portugal and Africa) and in the Mediterranean area where this species lives at a depth of 20-50 m. Ristori (1891b) reported some incomplete dactyli from the Pliocene sands of Monte Mario (Rome) (now assigned to the Early Pleistocene by Cosentino et al., 2009) ascribed to Pagurus striatus (Latreille, 1803), juvenile synonym of Dardanus arrosor (Herbst, 1796).

Dardanus substriatus (A. Milne Edwards, 1861)

Fig. 1C

Material and measurements: 3 left propodi (MSNM i27886 - hpa: $11 \mathrm{~mm}$; ld: $7 \mathrm{~mm}$; li: $3 \mathrm{~mm}$; lpa: $11 \mathrm{~mm}$; MSNM i27888 - hpa: $7 \mathrm{~mm}$; ld: $5 \mathrm{~mm}$; li: $2 \mathrm{~mm}$; lpa: 7 mm; MSNM i27889 - ld: 5 mm; li: 2 mm).

Description: Palm as long as high, with upper and lower margins converging anteriorly; palm covered with sinuous transverse crests, dentate anteriorly; short subtriangular index, very wide at the base and covered with dentate crests; occlusal margin weakly dentate; subtriangular dactylus longer than index.

Discussion. The studied propodi differ from those of Dardanus arrosor in having a shorter palm with upper and lower margins converging anteriorly and more numerous and raised crests, interlaced with each other like "scale fish". Based upon these characters the studied propodi are assigned to D. substriatus, reported from the Pliocene of Piedmont (Sismonda, 1846; A. Milne Edwards in Sismonda, 1861), Tuscany (Ristori, 1886; De Angeli et $a l ., 2009$ ), and from the Early Pliocene (now Early Pleistocene, see Baldanza et al., 2014) of Umbria (Pasini \& Garassino, 2010).

Genus Paguristes Dana, 1851

Type species: Paguristes hirtus Dana, 1853, by subsequent designation of Stimpson (1859).

Included fossil species: see Schweitzer et al. (2010: 54).

Paguristes cf. P. syrtensis de Saint Laurent 1970

Fig. 1D

Material and measurements: One incomplete dorsal shield (MSNM i27901).

Description: Sub-ovoid shield longer than broad, with anterior lateral margins sloping, sub-parallel, slightly convex medially; posterior region not preserved; pointed post antennal projection, concave ocular incision bordered by a marked elevate rim; rostrum partially preserved, with parallel carinate margins; narrow anterior region slightly inflated centrally; anterior lateral region with sparse irregular pits more coarse anteriorly; subelliptic central part of the shield marked by transverse striae and pits, divided by a smooth and short medial gastric groove; medial section of central part of the shield nearly flat; cervical groove partially preserved on the left side of the posterolateral region, linea transversalis not preserved.

Discussion. The general morphology of the shield is characteristic of Paguridae. Indeed, many morphological affinities with the extant Paguristes syrtensis de Saint Laurent 1970, widespread in the Mediterranean area, in having the same carapace shape, ridged supraorbital margins, and an elongate nostrum restricted axially (Falciai \& Minervini, 1992). Paguristes eremita (Linnaeus, 1767), also present in the Mediterranean area, has shorter rostrum. This is the first record for the species from the Pleistocene of southern Italy and from the Mediterranean basin.

Family Paguridae Latreille, 1802

Genus Anapagurus Henderson, 1886

Type species: Pagurus laevis Bell, 1846, by subsequent designation of Holthuis (1962).

Included fossil species: see Schweitzer et al. (2010: 55); Pasini \& Garassino (2011: 59).

Anapagurus sp.

Fig. 1E

Material and measurements: 3 left propodi, lacking dactyli (MSNM i27890 - hpa: 9 mm; li: $5 \mathrm{~mm}$; lpa: $7 \mathrm{~mm}$; MSNM i27891 - hpa: 5 mm; li: 2 mm; lpa: 4 mm; MSNM i 27892 - hpa: $4 \mathrm{~mm}$; li: $1 \mathrm{~mm}$; lpa: $2 \mathrm{~mm}$ ). 
Description: Propodus with convex transverse section and granulate outer surfaces; palm with oblique carpopropodus articulation; palm with convex lower margin and short straight dorsal margin; stout triangular index with transverse occlusal margin bearing a rim of small short tubercles.

Discussion. The studied propodi show the typical characters of Paguridae Latreille, 1802 and mainly of Anapagurus Henderson, 1886. Moreover, the studied specimens show some morphological affinities with the extant $A$. hyndmanni (Bell, 1846).

The fossil record of Anapagurus from Italy and Mediterranean basin is very scarce to date and limited to a single specimen of Anapagurus sp, from the Pleistocene of Arda River (Emilia Romagna, northern Italy) (Garassino \& De Angeli, 2004a), and to A. mamertinus Pasini \& Garassino, 2011, from the Pliocene of Capo Milazzo (Sicily) (Pasini \& Garassino, 2011).

Infraorder Brachyura Latreille, 1802

Section Podotremata Guinot, 1977

Subsection Raninoidia De Haan, 1839

Superfamily Raninoidea De Haan, 1839

Family Raninidae De Haan, 1839

Subfamily Notopodinae Serène \& Umali, 1972

Genus Ranilia H. Milne Edwards, 1837

Type species: Ranilia muricata H. Milne Edwards, 1837 , by monotypy. 73).

Included fossil species: see Schweitzer et al. (2010:

Ranilia constricta (A. Milne Edwards, 1880)

Material and measurements: Two carapaces nearly complete (MSNM i27877 - lcxp: $18 \mathrm{~mm}$; wcxp: $12 \mathrm{~mm}$; MSNM i27878 - lcxp: $20 \mathrm{~mm}$; wexp: $15 \mathrm{~mm}$ ); two loose palms, one dactylus, and one merus (MSNM i27915).

Description: Sub-oval carapace, strongly convex in transverse section, almost straight in midline; slightly raised front with prominent pointed spines; maximum width of the carapace between the prominent elongate lateral spines; lateral margins convergent posteriorly towards the short and gently convex posterior margin; stout chelipeds with tubercles and ciliate lines; elongate, pointed dactylus downward directed distally; palms longer than high with a ventral distal distinct spine; merus granulate dorsally, smooth ventrally with sparse pits; blunt distal dorsal spine.

Discussion. Garassino \& De Angeli (2008) reported Ranilia constricta from the Late Pleistocene of Bovetto district (Reggio Calabria), with an additional updated emended diagnosis of the species, whereas Vazzana (2008) reported the same species from Trumbacà district, strictly close to Bovetto. The studied specimens show the main morphological characters of Ranilia constricta to which they are assigned. Recent $R$. constric$t a$ is widespread from Western to Central and Western Atlantic.
Subfamily Ranininae De Haan, 1839

Genus Ranina Lamarck, 1801

Type species: Cancer raninus Linnaeus, 1758, by subsequent designation of Latreille (1810). 74).

Included fossil species: see Schweitzer et al. (2010:

Ranina propinqua Ristori, 1891

Fig. 1F

Material and measurements: One incomplete carapace (MSNM i27876 - lcxp: $47 \mathrm{~mm}$ ).

Description: Carapace convex dorsally, covered by subtriangular granular tubercles, uniformly arranged along the antero- and posterolateral margins, more scarce on gastric regions; anterolateral spines incomplete.

Discussion. Pasini, Garassino \& De Angeli in Baldanza et al. (2014: 274) discussed the specimens of Ranina known to date in the fossil record of Italy, re-describing the main characters of Ranina propinqua. The studied specimen preserves just the left side of the carapace, including the preorbital and the incomplete extraorbital spines, showing the main characters of Ranina Lamarck, 1801. Moreover, the above-mentioned characters of the studied specimen are typical of $R$. propinqua, to which it is assigned. Ranina propinqua was previously described from Pliocene sandy deposits of Via della Madonna degli Angeli in Città della Pieve (Perugia, Umbria, central Italy) by Ristori (1891a) [these deposits are now referred to the Gelasian-Calabrian interval (Early Pleistocene) see Baldanza et al., 2014)]; and recently from the Early Pleistocene of Fabro Scalo (Terni, Umbria, central Italy) by Baldanza et al. (2014) and from the Early Pleistocene of Orzalume Cottano area (Orvieto, Umbria, central Italy) (Famiani et al., in press). The discovery of $R$. propinqua from Trumbacà, attests the presence of Ranina in the southern Mediterranean area still during the Tyrrhenian (Late Pleistocene).

Section Eubrachyura de Saint Laurent, 1980

Subsection Heterotremata Guinot, 1977

Superfamily Leucosioidea Samouelle, 1819

Family Leucosiidae Samouelle, 1819

Subfamily Ebaliinae Stimpson, 1871

Genus Ebalia Leach, 1817

Type species: Ebalia bryerii Leach, 1817, by subsequent designation of Rathbun (1922).

Included fossil species: see Schweitzer et al. (2010: 87).

Ebalia cf. E. deshayesi Lucas, 1846

Fig. 2A

Material and measurements: One complete carapace (MSNM i27902 - lcpx: 4 mm; wcpx: $7 \mathrm{~mm}$ ).

Description: Octagonal carapace, slightly wider than long, convex dorsally and with small tubercles on gastric and branchial regions; wide developed bugle on the cardiac region; lateral and posterolateral margins slightly concave. 


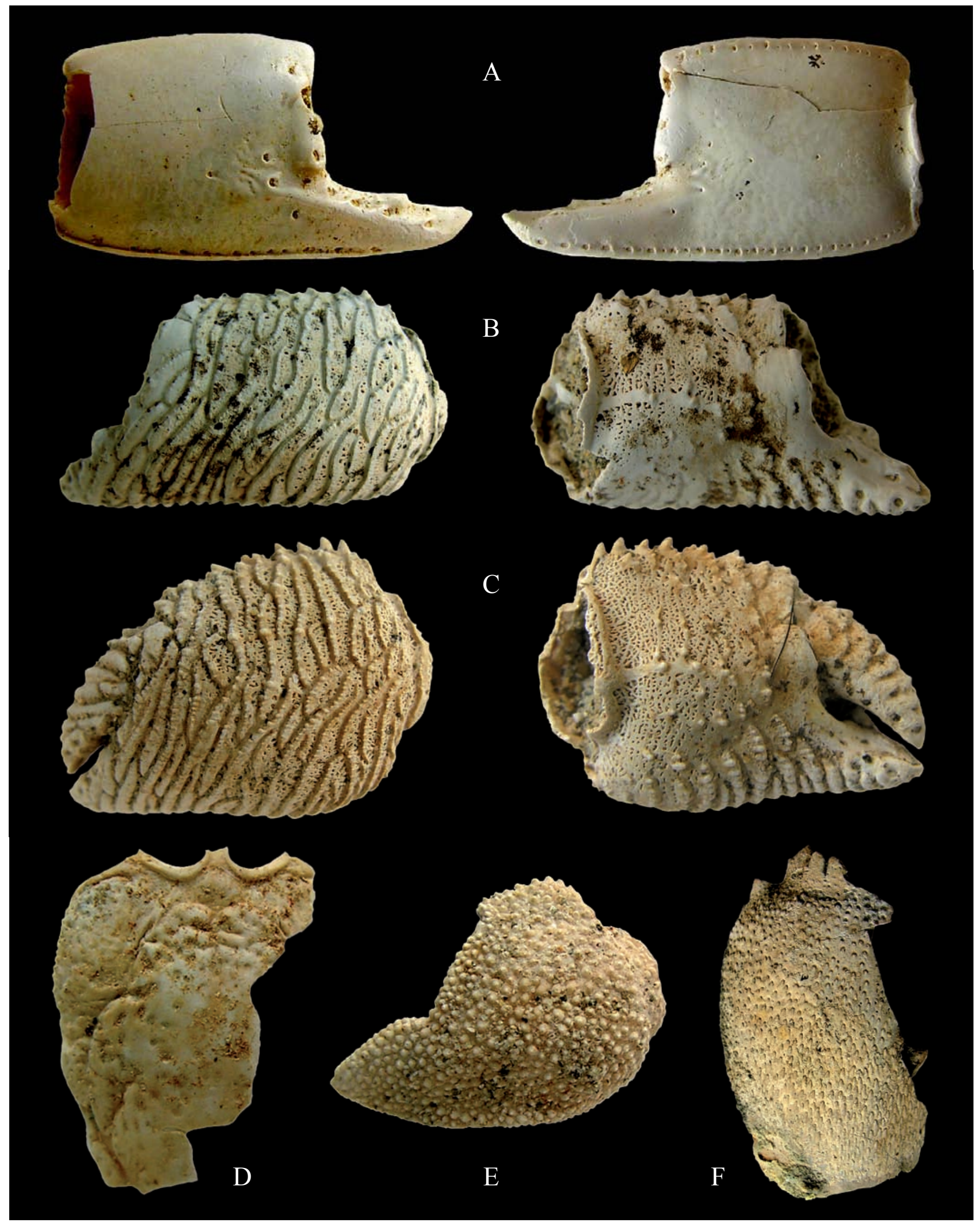

Fig. 1 - A) ?Corallianassa sp., MSNM i27900, right chela, outer and inner views (x 6.1). B) Dardanus arrosor (Herbst, 1796), MSNM i27885, right chela, outer and inner views (x 3.7). C) Dardanus substriatus (A. Milne Edwards, 1861), MSNM i27886, left chela, outer and inner views (x 3.8). D) Paguristes cf. P. syrtensis de Saint Laurent 1970, MSNM i27901, dorsal shield (x 6). E) Anapagurus sp., MSNM i27890, left chela, outer view (x 4.6). F) Ranina propinqua Ristori, 1891, MSNM i27876, incomplete carapace in dorsal view (x 1.3). 
Discussion. As pointed out by De Angeli et al. (2009: 178), "the high degree of sexual dimorphism among adults, the remarkable morphological differences between adults and juvenile stages, and the extremely variable morphology of carapace in the same species, makes the right classification of the species ascribed to this genus difficult". The studied specimen, however, shows morphological affinities with extant Ebalia deshayesi Lucas, 1846, in having an octagonal carapace, slightly wider than long, with small tubercles on gastric and branchial regions, wide developed bugle on the cardiac region, and having lateral and posterolateral margins slightly concave. Based upon these main characters, the studied specimen is tentatively assigned to Ebalia $\mathrm{cf}$. E. deshayesi Lucas, 1846.

This fossil species was previously reported by De Angeli et al. (2009), from the Early Pliocene of Poggio alla Staffa, Siena (Tuscany, central Italy). Therefore, it represents the first record from the Pleistocene of southern Italy and from the Mediterranean basin. Extant E. deshayesi is widespread in Eastern Atlantic (Balearic Islands) and Mediterranean Sea, living in sandy and muddy bottoms (Zariquiey Álvarez, 1968).

Genus Ilia Leach, 1817

Type species: Cancer nucleus Linnaeus, 1758, by monotypy.

Included fossil species: see Schweitzer et al. (2010: $87,88)$.

Ilia nucleus (Linnaeus, 1758)

Fig. 2B

Material and measurements: One complete carapace (MSNM i27903 - lcxp: $10 \mathrm{~mm}$; wcxp: $7 \mathrm{~mm}$ ).

Discussion. Zariquiey Álvarez (1968) pointed out the main diagnostic characters of Ilia nucleus, as follows: typical globular carapace, slightly longer than wide; very narrow subacutely bidentate front; posterior margin with well-developed, rounded two median lobes, and one strong spine upward-directed on either lateral margins. We ascribe the studied specimens to the extant I. nucleus, because it shares the same above-mentioned morphological characters. A review of the morphological characters of this species carried on by Garassino and Pasini (2012), pointed out that all the specimens previously reported from the Pliocene of Italy and erroneously ascribed to I. pliocaenica Ristori, 1891, should be instead ascribed to I. nucleus (for discussion see Garassino et al., 2010a, 2012, 27-30; Garassino \& Pasini, 2012, 43-46). Moreover I. nucleus, was recently reported from the Early Pleistocene (Emilian) of Pomezia (Roma, Lazio, central Italy) (Garassino et al., 2010a; Garassino \& Pasini, 2012), and from the Zanclean (Early Pliocene) of "La Serra" quarry (Pisa, Tuscany, central Italy) by Garassino et al. (2012). Extant I. nucleus is widespread in the Mediterranean Sea, living imbedded in sandy bottoms from 5 to 160 meters deep.

Note. The studied specimen shows direct evidence of a predation consisting of an ovoid submillimetric drilled hole into the dorsal gastric region. This kind of holes (ichnotaxon Oichnos ovalis) has been attributed to possibly octopods with some figured examples (Klompmaker et al., 2013: 606, 605, fig. 3). Similar boreholes of comparable size and form, were previously reported also from the fossil decapod leucosiid Ristoria pliocaenica (Ristori, 1891) from the Early Pliocene of the "La Serra" quarry by Pasini \& Garassino (2012: 263, 261, Fig. 3 A, B). This report expands the scarce record on fossil decapod crab predation found in the worldwide Cenozoic (for discussion see Klompmaker et al., 2013).

Superfamily Dorippoidea MacLeay, 1838

Family Dorippidae MacLeay, 1838

Genus Medorippe Manning \& Holthuis, 1981

Type species: Cancer lanatus Linnaeus, 1767, by original designation.

Included fossil species: see Schweitzer et al. (2010: 79).

Medorippe lanata (Linnaeus, 1767)

Fig. 2C

Material and measurements: One carapace, including pleon (MSNM i27884 - lcxp: $21 \mathrm{~mm}$; wcxp: 27 $\mathrm{mm})$.

Description: Flat subexagonal carapace, wider than long, with deep groves and distinct tubercles; lateral margins converging anteriorly, larger posteriorly; short front; long anterolateral margins with a strong branchial spine; two tubercles present behind the triangular frontal teeth; anterolateral and outer orbital pointed teeth; regions well marked dorsally; smooth hepatic, branchial, and supraorbital regions separated by deep groves; sinuous posterior margin, with s1-s3 exposed dorsally.

Discussion. The main characters of the carapace and pleon allow to ascribe the studied specimen to a male individual of Medorippe lanata. Gemmellaro (1914) reported some specimens from the Sicilian (Late Pleistocene) of Sicily (southern Italy), housed in Marquis of Monterosato's private collection (repository and catalogue number unknown), probably today lost (De Angeli \& Garassino, 2006a). This is the second fossil record for the species in the Mediterranean area. Extant M. lanata is widespread in the Eastern Atlantic, Mediterranean Sea and South-West Africa coasts (Holthuis \& Manning, 1990). Medorippe lanata specially inhabits muddy and muddy-sandy bottoms, ranging from a few metres to 75 meters deep in the Mediterranean area (Falciai \& Minervini, 1992).

Superfamily Calappoidea De Haan, 1833

Family Calappidae De Haan, 1833

Genus Calappa Weber, 1795

Type species: Cancer granulatus Linnaeus, 1758, by subsequent designation of Latreille (1810).

Included fossil species: see Schweitzer et al. (2010: $82,83)$. 
Calappa granulata (Linnaeus, 1758)

Fig. 2D, E

Material and measurements: Two carapaces (MSNM i27906 - lcxp: $11 \mathrm{~mm}$; wcxp: $15 \mathrm{~mm}$; i27907 - incomplete); two right and one left complete propodus (MSNM i27893 - hpa: $22 \mathrm{~mm}$; ld: $13 \mathrm{~mm}$; li: $8 \mathrm{~mm}$; lpa: $16 \mathrm{~mm}$; MSNM i27894 - hpa: $18 \mathrm{~mm}$; ld: $12 \mathrm{~mm}$; li: $5 \mathrm{~mm}$; lpa: $14 \mathrm{~mm}$; MSNM i27895 - hpa: $16 \mathrm{~mm}$; ld: $10 \mathrm{~mm}$; li: 5 $\mathrm{mm}$; lpa: $12 \mathrm{~mm}$ ); four right dactyli (MSNM i27896 - ld: $23 \mathrm{~mm}$; MSNM i27897 - ld: 21 mm; MSNM i27898 - ld: 10 mm; MSNM i27899 - ld: 8 mm).

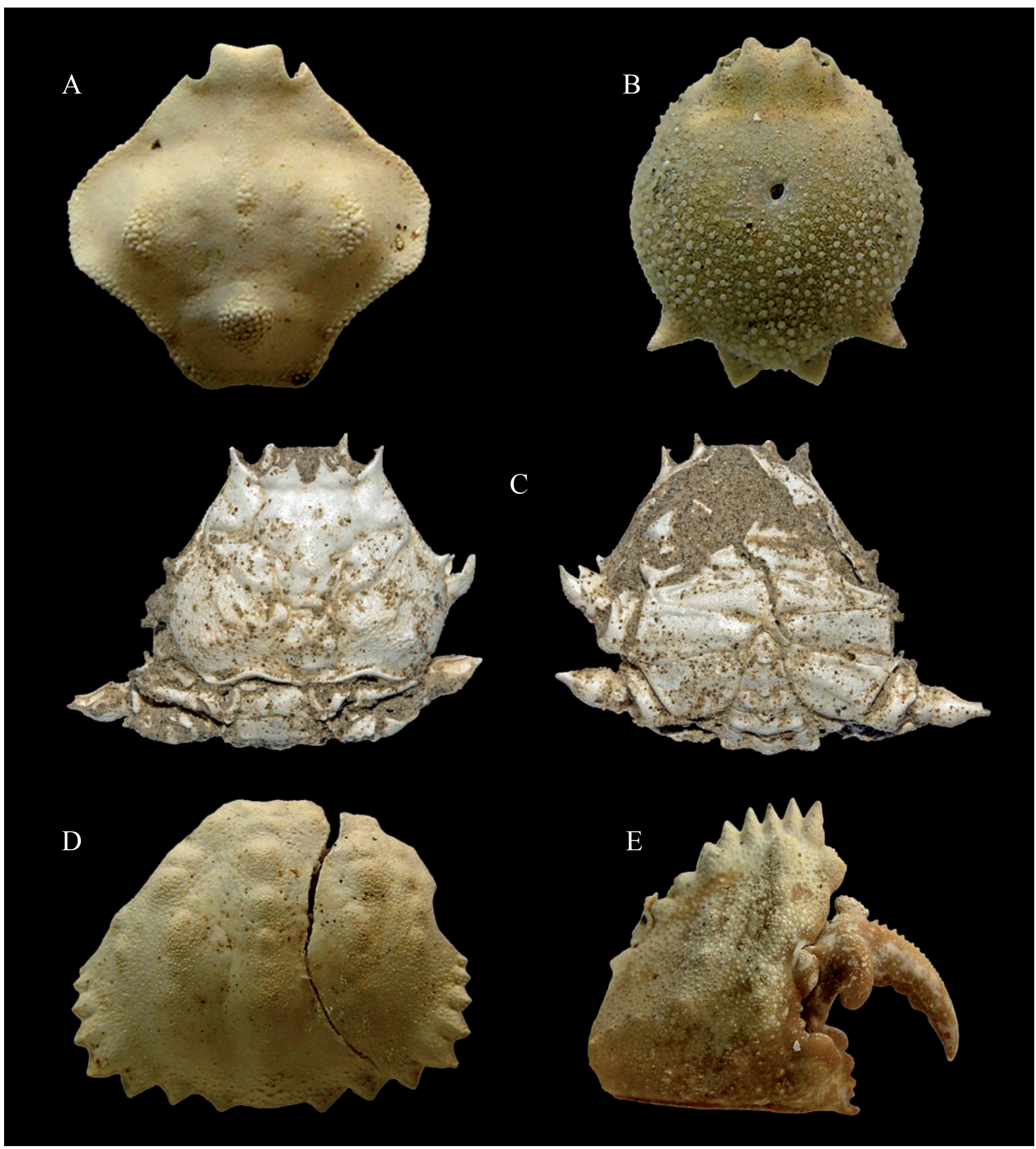

Fig. 2 - A) Ebalia cf. E. deshayesi Lucas, 1846, MSNM i27902, carapace in dorsal view (x 12). B) Ilia nucleus (Linnaeus, 1758), MSNM i27903, carapace in dorsal view (x 6). C) Medorippe lanata (Linnaeus, 1767), MSNM i27884, carapace in dorsal and ventral views (x 2). D) Calappa granulata (Linnaeus, 1758), MSNM i27906, incomplete carapace in dorsal view (x 4.6). E) Calappa granulata (Linnaeus, 1758), MSNM i27893, right chela, outer view (x 2.5). 
Description: Postero-lateral margins of the granulate carapace strongly convergent with triangular teeth; regions well marked by two longitudinal grooves dividing the dorsal surface of carapace in three parts bearing blunt lined tubercles; subtriangular propodus, higher anteriorly; upper margin with a rim of pointed triangular spines; lower margin with a longitudinal row of small granulations; outer margin of propodus with some granulations; short triangular index curved downward distally; robust long pointed dactylus strongly curved, directed-downward distally with granulations along the upper margin and a typical strong prominence on the basis of the outer margin.

Discussion. The studied specimens have the typical morphological characters of the representatives of Calappidae and they have been assigned to the fossil Calappa granulata. This species was previously reported from the Pliocene of Tuscany, Piedmont, Emilia Romagna and Sicily; from the Pleistocene of Monte Pellegrino (Sicily); from the Early Pleistocene of Poggio i Sodi (Siena, Tuscany), and Fabro Scalo (Terni, Umbria) (Ristori, 1891a; Gemmellaro, 1914; Garassino \& De Angeli, 2004a; Garassino et al., 2004; De Angeli et al., 2009; Pasini \& Garassino, 2012; Baldanza et al., 2013; 2014; Garassino \& Pasini, 2013; Pasini \& Garassino, 2013). Extant C. granulata is widespread in the Mediterranean Sea, living usually in sandy, muddy and detrital bottoms from 30 to 150 meters deep.

Family Epialtidae MacLeay, 1838

Subfamily Pisinae Dana, 1851

Genus Pisa Leach, 1814

Type species: Cancer biaculeatus Montagu, 1813, by monotypy.

Included fossil species: see Schweitzer et al. (2010: 93).

Pisa armata (Latreille, 1803)

Fig. 3A

Material and measurements: One right propodus with carpus lacking dactylus (MSNM i27880 - hpa: $11 \mathrm{~mm}$; li: $6 \mathrm{~mm}$; lpa: $12 \mathrm{~mm}$ ); one left propodus lacking dactylus and carpus (MSNM i27881 - hpa: $9 \mathrm{~mm}$; li: $5 \mathrm{~mm}$; lpa: $10 \mathrm{~mm}$ ); one incomplete left propodus (MSNM i27882 - li: $5 \mathrm{~mm}$ ).

Description: Propodus with smooth rectangular palm, longer than high, with rounded dorsal and lower margins, slightly inflated medially, compressed at the insertion with the dactylus; typical index with lower margin strongly curved downward-directed proximally, then forward-directed and spooned at the tip; a rim of small teeth is present along the outer margin; trigonal short carpus with stout rounded tubercles.

Discussion. Even though incomplete, we ascribe confidently to this species three propodi for the abovementioned characters, sharing with the propodus of the extant Pisa armata. This species was already reported in the fossil record of Italy from the Early Pliocene of "La Serra" quarry (Pisa, Tuscany, central Italy) (Garassino et al., 2012), and from the Late Pleistocene of Monte Pellegrino (Palermo, Sicily, southern Italy) (Gemmellaro, 1914). In the Mediterranean Sea, P. armata occupies usually rocky hard grounds or mud-sandy rich in weeds, ranging from 1 to 500 meter deep, but commonly between 50-160 meter deep (Falciai \& Minervini, 1992).

Superfamily Parthenopoidea MacLeay, 1838

Family Parthenopidae MacLeay, 1838

Subfamily Parthenopinae MacLeay, 1838

Genus Derilambrus Tan \& Ng, 2007

Type species: Parthenope angulifrons Latreille, 1825, by original designation.

Included fossil species: Derilambrus angulifrons (Latreille, 1825).

Derilambrus cf. D. angulifrons (Latreille, 1825)

Material and measurements: Two small incomplete ?meri (MSNM i27905).

Description: Elongate ?meri, trigonal in transverse section, and strong spines arrayed in longitudinal rows along the margins.

Discussion. The studied small specimens show elongate ?meri, trigonal in transverse section, and strong spines arrayed in longitudinal rows along the margins, typical characters of the representatives of the family Parthenopidae and especially of Derilambrus Tan \& Ng, 2007. The specimens could be tentatively ascribed to juvenile individuals of Derilambrus cf. $D$. angulifrons, previously reported in the fossil record of Italy from the Sicilian (Early Pleistocene) of Favignana Island (Sicily, southern Italy) by Garassino \& De Angeli (2004b), and from the Zanclean (Early Pliocene) of "La Serra" quarry (Pisa, Tuscany, central Italy), by Garassino et al. (2012). Moreover we point out that the very similar, small chelipeds described by Ristori (1891b) from the Pliocene (now Pleistocene) of Monte Mario (Rome, central Italy), and by Garassino \& De Angeli (2004a) from the Pliocene and Pleistocene of Emilia Romagna (northern Italy), ascribed respectively to Lambrus? sp. and to Parthenope sp., could be also assigned to $D$. angulifrons. The extant species lives at depths between 2 and 80 meter deep in the Mediterranean Sea and southwestern Spain, inhabiting on mudsandy bottoms or along submarine seamounts and knol$1 \mathrm{~s}$ in deeper waters.

Superfamily Cancroidea Latreille, 1802

Family Atelecyclidae Ortmann, 1893

Genus Atelecyclus Leach, 1814

Type species: Cancer (Hippa) septemdentatus Montagu, 1813, by monotypy. 
Included fossil species: see Schweitzer et al. (2010: 100).

Atelecyclus undecimdentatus (Herbst, 1783)

Fig. 3B

Material and measurements: One right cheliped, lacking dactylus (MSNM i27879 - hpa: $11 \mathrm{~mm}$; li: $6 \mathrm{~mm}$; lpa: $14 \mathrm{~mm}$ ).

Discussion. The studied specimen shows close affinities with the cheliped of the fossil and extant Atelecyclus undecimdentatus (Herbst, 1783), as described and figured by Garassino et al. (2012: 38; fig.18 B), having palm of cheliped slightly convex, trapezoidal in outline, spinate dorsally, with three distinct longitudinal tuberculate rims and index downward-directed. Based upon these peculiar characters, we ascribe the specimen to $A$. undecimdentatus. This species was previously reported by Garassino et al. (2012) from the Zanclean (Early Pliocene) of "La Serra" quarry (Pisa, Tuscany, central Italy). Extant $A$. undecimdentatus lives in the eastern Atlantic and, less commonly, in Mediterranean Sea from $1 \mathrm{~m}$ to $60 \mathrm{~m}$ deep on sandy or gravel bottoms.

Superfamily Portunoidea Rafinesque, 1815

Family Portunidae Rafinesque, 1815

Subfamily Carcininae MacLeay, 1833

Genus Carcinus Leach, 1814

Type species: Cancer means Linnaeus, 1758, by monotypy. date.

Included fossil species: any fossil species known to

\section{Carcinus sp.}

Material and measurements: Two loose dactyli (MSNM i28013 - ld: 14 mm; MSNM i28014 - ld: 12 $\mathrm{mm})$.

Discussion. We ascribe tentatively two complete dactyli partially washed to this genus. Dactyli are strong, elongate, curved with pointed tips, bearing a rim of short teeth on the occlusal margin. This kind of dactylus is present in Carcinus Leach, 1814, widespread in the Mediterranean Sea and Atlantic Ocean. The studied specimens show affinities with the dactyli previously reported by Garassino \& De Angeli (2004a: 44, fig. 8) from the Pliocene of Campore (Parma, Emilia Romagna, N Italy), also referred to Carcinus s.l.

Superfamily Pilumnoidea Samouelle, 1819

Family Pilumnidae Samouelle, 1819

Subfamily Pilumninae Samouelle, 1819

Genus Pilumnus Leach, 1815

Type species: Cancer hirtellus Linnaeus, 1761, by monotypy.

Included fossil species: see Schweitzer et al. (2010: 120).
Pilumnus hirtellus (Linnaeus, 1761)

Fig. 3C, D

Material and measurements: One complete carapace (MSNM i27904-1cpx: $6 \mathrm{~mm}$; wcpx: $8 \mathrm{~mm}$ ) and three right chelipeds (MSNM i27912, i27913 - hpa: 7 mm; ld: $5 \mathrm{~mm}$; li: $3 \mathrm{~mm}$; lpa: 9 mm; MSNM i27914 ld: $7 \mathrm{~mm}$; li: $5 \mathrm{~mm}$ ).

Description: Subcircular carapace, wider than long, with anterolateral margins with four spines (excluding postorbital spine); smooth dorsal surface of the carapace with many pits.

Discussion. The above-mentioned characters are shared with the extant Pilumnus hirtellus (Linnaeus, 1761), having anterolateral margins with four spines (excluding postorbital spine) and near smooth dorsal surface with many pits. This species was previously reported by Garassino et al. (2012), from the Zanclean (Early Pliocene) of the "La Serra" quarry (Pisa, Tuscany, central Italy). This is the first record of this species from the Pleistocene in Italy and in the southern Mediterranean basin. The extant $P$. hirtellus lives in northeastern Atlantic, Mediterranean and Black Sea.

Family Xanthidae MacLeay, 1838

Subfamily Xanthinae MacLeay, 1838

Genus Xantho Leach, 1804

Type species: Cancer incisus Leach, 1804, by monotуру.

Included fossil species: see Schweitzer et al. (2010: 128).

Xantho cf. X. incisus (Leach, 1814)

Fig. 3E

Material and measurements: One left cheliped (MSNM i27908 - hpa: $5 \mathrm{~mm}$; ld: $5 \mathrm{~mm}$; li: $4 \mathrm{~mm}$; lpa: $8 \mathrm{~mm}$ ) and two right chelipeds (MSNM i27909 - hpa: $4 \mathrm{~mm}$; ld: $3 \mathrm{~mm}$; li: $2 \mathrm{~mm}$; lpa: $6 \mathrm{~mm}$; MSNM i27911 - hpa: $6 \mathrm{~mm}$; ld: $4 \mathrm{~mm}$; li: $3 \mathrm{~mm}$; lpa: 8 $\mathrm{mm})$.

Discussion. The studied chelipeds show general morphological characters similar to Xanthidae MacLeay, 1839. Moreover, the dorsal palm and merus ornamentation with coarse rugae and deep pits, closely resembles chelipeds of Xantho incisus (Leach, 1814). Beside the small sized and short dactylus are also typical characters of the female individuals. Based upon these observations, we ascribe tentatively both the specimens to female individuals of Xantho cf. $X$. incisus. This is the first report for the species from the Mediterranean fossil record.

The extant species lives in Mediterranean Sea on rocky environments, ranging from the subtidal level down to depths of about 100 meters (Zariquiey Álvarez, 1968). 


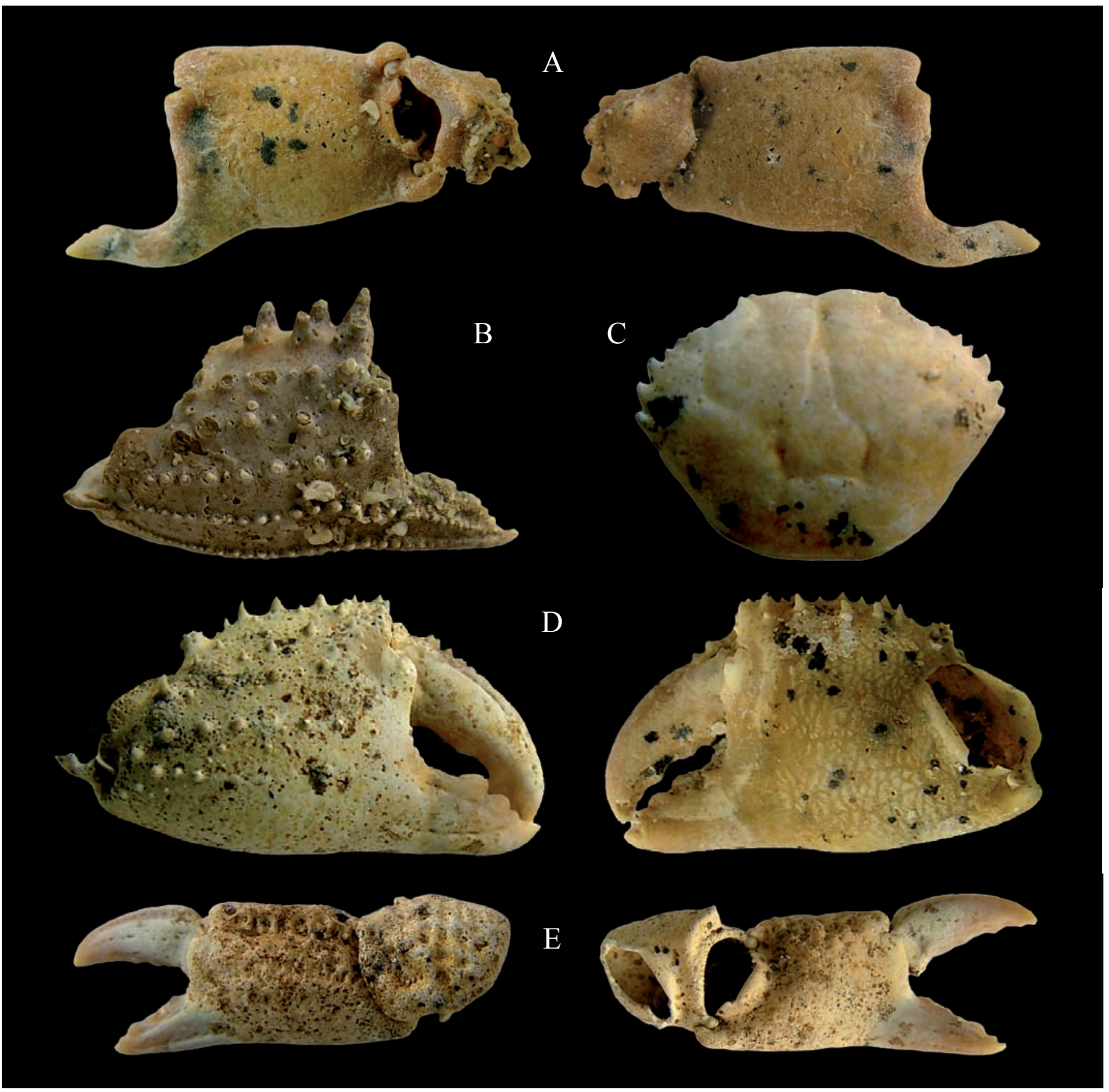

Fig. 3 - A) Pisa armata (Latreille, 1803), MSNM i27880, right chela, outer and inner views (x 3.2). B) Atelecyclus undecimdentatus (Herbst, 1783), MSNM i27879, right chela, outer view (x 3.7). C) Pilumnus hirtellus (Linnaeus, 1761), MSNM i27904, carapace in dorsal view (x 8.5). D) Pilumnus hirtellus (Linnaeus, 1761), MSNM i27912, right chela, outer and inner views (x 7.5). E) Xantho cf. X. incisus (Leach, 1814), MSNM i27908, left chela, outer and inner views (x 4.6).

\section{REMARKS ON THE DECAPOD ASSEMBLAGE}

The studied decapod assemblage, even though incomplete, shows the modernity of the extant Mediterranean fauna since the Tyrrhenian (Late Pleistocene), with the presence of species actually living along the Italian coasts of the Mediterranean Sea. Among the studied species, Paguristes cf. P. syrtensis and Xantho cf. X. incisus are reported for the first time in the Mediterranean fossil record, whereas two species belonging to Raninidae, the extant-fossil Ranilia constricta (actually living in Western, Central and Eastern Atlantic) and the fossil
Ranina propinqua are extinct in the Mediterranean basin, most probably due the selective climatic-environmental changes that occurred during the Holocene. Similarly, Corallianassa also does not inhabit the Mediterranean Sea today. Unfortunately, many others specimens collected from Trumbacà, belonging to different taxa, are too badly or poorly preserved, not allowing a systematic attribution. We hope future discoveries of well-preserved specimens will allow further knowledge of this very rich assemblage at the origin of the extant living Mediterranean decapod fauna. 


\section{Acknowledgements}

We wish to thank Piero Frediani, Gruppo Paleontologico "C. De Giuli", Castelfiorentino (Firenze), for useful information on the Trumbacà outcrops; and Francisco J. Vega, Instituto de Geología, Universidad Nacional Autónoma de México, Ciudad Universitaria (Coyoacán, México) and Torrey Nyborg, Department of Earth and Biological Sciences, Loma Linda University (Loma Linda, U.S.A.) for careful review and criticism. Matúš Hyžný's research has been supported by Austrian Science Fund (FWF; Lise Meitner Program M 1544-B25).

\section{REFERENCES}

Baldanza A., Bizzarri R., Famiani F., Garassino A., Hyžný M. \& Pasini G., 2013 - The bathyal decapod crustacean community from the Poggio i Sodi quarries (Siena Basin, Tuscany, Italy). Boletín de la Sociedad Geológica Mexicana, 65 (2): 335-353.

Baldanza A., Bizzarri R., Famiani F., Pasini G., Garassino A. \& De Angeli A., 2014 - Early Pleistocene shallow marine decapod crustaceans fauna from Fabro Scalo (western Umbria, central Italy): taxonomic inferences and palaeoenvironmental reconstruction. Neues Jahrbuch für Geologie und Paläontologie, Abhandlungen, 271 (3): 261-283.

Bonfiglio L., 1972 - Il Tirreniano di Bovetto e Ravagnese presso Reggio Calabria. Quaternaria, 16: 137-148.

Borradaile L. A., 1904 - Marine crustaceans. XIII. The Hippidea, Thalassinidea and Scyllaridea. In: The Fauna and Geography of the Maldive and Laccadive Archipelagoes; Being the Account of the Work carried on and of the Collections made by $n$ Expedition during the years 1899 and 1900. Gardiner J. S. (ed.). Cambridge University Press, 2: 750-754.

Cosentino D., Cipollari, P., Di Bella L., Esposito A., Faranda C., Giordano G., Gliozzi E., Mattei M., Mazzini I., Porreca M. \& Funiciello R., 2009 - Tectonics, sea-level changes and palaeoenvironments in the early Pleistocene of Rome (Italy). Quaternary Research, 72: 143-155.

De Angeli A. \& Garassino A., 2006a - Catalog and bibliography of fossil stomatopoda and decapoda from Italy. Memorie della Società italiana di Scienze naturali e del Museo civico di Storia naturale di Milano, 35 (1): 3-96.

De Angeli A. \& Garassino A., 2006b - New reports of decapod crustaceans from the Mesozoic and Cenozoic of Friuli-Venezia Giulia (NE Italy). Atti della Società italiana di Scienze naturali e del Museo civico di Storia naturale in Milano, 147 (2): 267-294.

De Angeli A., Garassino A. \& Pasini G., 2009 - New reports of anomurans and brachyurans from the Cenozoic of Tuscany (Italy). Atti della Società italiana di Scienze naturali e del Museo civico di Storia naturale in Milano, 150 (2): 163-196.

De Grave S., Pentcheff N. D., Ahyong S. T., Chan T.-Y., Crandall K. A., Dworschak P. C., Felder D. L., Feldmann R. M., Fransen C. H. J. M., Goulding L. Y. D., Lemaitre R., Low M. E. Y., Martin J. W., Ng P. K. L., Schweitzer C. E., Tan S. H., Tshudy D. \& Wetzer R., 2009 - A classification of living and fossil genera of decapod crustaceans. The Raffles Bulletin of Zoology, Suppl. 21: 1-109.
Dworschak P. C., 1992 - The Thalassinidea in the Museum of Natural History, Vienna; with some remarks on the biology of the species. Annalen des Naturhistorischen Museums in Wien, 93B: 189-238.

Falciai L. \& Minervini R., 1992 - Guida dei Crostacei Decapodi d'Europa. Muzzio Editore.

Famiani F., Baldanza A., Bizzarri R., De Angeli A., Garassino A. \& Pasini G., in press - New report of Ranina propinqua Ristori, 1891 (Brachyura, Raninidae) from central Italy. Nenes Jahrbuch für Geologie und Paläontologie.

Garassino A. \& De Angeli A., 2004a - Decapod crustacean fauna from the Pliocene and Pleistocene of Arda, Stirone and Enza Rivers (Piacenza, Parma and Reggio Emilia Provinces, N Italy). Atti della Società italiana di Scienze naturali e del Museo civico di Storia naturale in Milano, 145 (1): 29-57.

Garassino A. \& De Angeli A., 2004b - Parthenope angulifrons Latreille, 1825 and Atelecyclus rotundatus (Olivi, 1792) from the Sicilian (upper Pleistocene) of Favignana Island (Egadi Islands, Sicily, S Italy). Atti della Società italiana di Scienze naturali e del Museo civico di Storia naturale in Milano, 145 (1): 19-28.

Garassino A. \& De Angeli A., 2008 - Ranilia constricta (A. Milne Edwards, 1880) (Brachyura, Raninidae) from the Tyrrhenian (Upper Pleistocene) of Bovetto (Calabria, S Italy). Atti della Società Italiana di Scienze Naturali e del Museo Civico di Storia Naturale di Milano, 149 (1): 9-16.

Garassino A., DeAngeli A., Gallo L. M. \& Pasini G., 2004 Brachyuran and anomuran fauna from the Cenozoic of Piedmont (NW Italy). Atti della Società italiana di Scienze naturali e del Museo civico di Storia naturale in Milano, 145 (2): 251-281.

Garassino A. \& Pasini G., 2012 - Ilia nucleus (Linnaeus, 1758) (Crustacea: Decapoda: Brachyura: Leucosiidae) from the Early Pleistocene of central Italy, with remarks on I. pliocaenica Ristori, 1891. Neues Jahrbuch für Geologie und Paläontologie, Abhandlungen, 263 (1): 43-46.

Garassino A. \& Pasini G., 2013 - Calappa granulata (Linnaeus, 1758) (Crustacea, Decapoda, Brachyura, Calappidae) and Astiplax aspera n. gen., n. sp. (Crustacea, Decapoda, Brachyura, Goneplacidae) from the Asti sands Fm. (Late Pliocene) of S. Pietro (Asti, Piemonte, NW Italy). Boletín de la Sociedad Geológica Mexicana, 65 (2): 329-334.

Garassino A., Pasini A. \& De Angeli A., 2010a - Ilia nucleus (Linnaeus, 1758) from the Emilian (early Pleistocene) of Pomezia (Lazio, Central Italy). In: $4^{\text {th }}$ Symposium on Mesozoic and Cenozoic Decapod Crustaceans. Abstracts. Eichstatt, Germany: 14.

Garassino A., Pasini A. \& De Angeli A., 2010b - Homola barbata (Fabricius, 1793) from the Tyrrhenian (late Pleistocene) of Calabria (S Italy) In: $4^{\text {th }}$ Symposium on Mesozoic and Cenozoic Decapod Crustaceans. Abstracts. Eichstatt, Germany: 15.

Garassino A., Pasini G., De Angeli A., Charbonnier S., Famiani F., Baldanza A. \& Bizzarri R., 2012 - The decapod community from the Early Pliocene (Zanclean) of "La Serra" quarry (San Miniato, Pisa, Toscana, central Italy): sedimentology, systematics, and palaeoenvironmental implications. Annales de Paléontologie, 98: 1-61. 
Gemmellaro M., 1914 - Crostacei e pesci fossili del "Piano Siciliano" dei dintorni di Palermo. Giornale di Scienze Naturali ed Economiche di Palermo, 30: 73-94.

Holthuis L. B., 1962 - Forty-seven genera of Decapoda (Crustacea); proposed addition to the Official List. Z. N. (S.) 1499. Bulletin of Zoological Nomenclature, 19 (4): $236-253$.

Holthuis L. B. \& Manning R. B., 1990 - Crabs of the subfamily Dorippinae MacLeay, 1838, from the IndoWest Pacific Region (Crustacea: Decapoda: Dorippidae). Researches in Crustacea, Special No. 3: 1-151.

Hyžný M. \& Müller P. M., 2012 - The fossil record of Glypturus Stimpson, 1866 (Crustacea, Decapoda, Axiidea, Callianassidae) revisited, with notes on palaeoecology and palaeobiogeography. Palaeontology, 55 (5): 967-993.

Klompmaker, A. A., Karasawa H., Portell R. W., Fraaije R. H. B. \& Ando Y., 2013 - An overview of predation evidence found on fossil decapod crustaceans with new examples of drill holes attributed to gastropods and octopods. Palaois, 28 (9): 599-613.

Latreille, P. A., 1810 - Considérations génerales sur l'Ordre naturel des Animaux composant les Classes des Crustacés, des Arachnides et des Insectes; avec un tableau Méthodique de leurs genres, disposes en famille. Paris.

Manning R. B. \& Felder D. L., 1991 - Revision of the American Callianassidae (Crustacea: Decapoda: Thalassinidea). Proceedings of the Biological Society of Washington, 104 (4): 764-792.

Ngoc-Ho N., 2003 - European and Mediterranean Thalassinidea (Crustacea, Decapoda). Zoosystema, 25 (3): 439-555.

Ng P.K.L., Guinot D. \& Davie P.J., 2008 - Systema Brachyurorum: Part I. An annotated checklist of extant brachyuran crabs of the world. The Raffles Bulletin of Zoology, Suppl. No.17: 1-286.

Pasini G. \& Garassino A., 2010 - New report of Dardanus substriatus (A. Milne-Edwards, 1861) (Anomura, Paguroidea, Diogenidae) from the Early Pliocene of Ficulle, Terni (Umbria, Central Italy). Atti della Società italiana di Scienze naturali e del Museo civico di Storia naturale in Milano, 151 (1): 113-116.

Pasini G. \& Garassino A., 2011 - Anapagurus mamertinus n. sp. (Anomura, Paguroidea, Paguridae) from the Pliocene of S. Antonio, Capo Milazzo (Sicily, S Italy). Atti della Società italiana di Scienze naturali e del Museo civico di Storia naturale in Milano, 152 (1): 57-62.

Pasini G. \& Garassino A., 2012 - Naticid gastropod and octopodid cephalopod predatory traces: evidence of drill holes on the leucosid crab Ristoria pliocaenica (Ristori, 1891), from the Pliocene of the "La Serra" quarry (Tuscany, Italy). Atti della Società italiana di Scienze naturali e del Museo civico di Storia naturale in Milano, 153 (2): 257-266.

Pasini G. \& Garassino A., 2013 - Records of brachyuran crabs from the Pliocene (Piacenzian) of Reggio Emilia (Emilia Romagna, N Italy). Boletín de la Sociedad Geologica Mexicana, 6 (2): 319-328.

Poore G. C. B. \& Griffin D. J. G., 1979 - The Thalassinidea (Crustacea: Decapoda) of Australia. Records of the Australian Museum, 32 (6): 217-321.
Rathbun M. J., 1906 - The Brachyura and Macrura of the Hawaiian islands. Bulletin of the Bureau of Fisheries, 23 (3): 827-930.

Rathbun M. J., 1922 - Opinion 73. Five generic names in Crinoidea, eighty-six generic names in Crustacea, and eight names in Acarina, placed on the Official List of Generic names. Opinion Rendered by International Commission on Zoological Nomenclature. Smithsonian Miscallaneous Collections, 73 (1): 23-31.

Ristori G., 1886 - I crostacei brachiuri e anomuri del Pliocene italiano. Bollettino della Società Geologica Italiana, 5: 93-128.

Ristori G., 1891a - Contributo alla fauna carcinologica del Pliocene italiano. Atti della Società Toscana di Scienze Naturali, Memorie, 11: 3-18.

Ristori G., 1891b - I crostacei fossili di Monte Mario. Atti della Società Toscana di Scienze Naturali, Memorie, 11: 19-25.

Sakai K., 1967 - Three new species of Thalassinidea (Decapoda, Crustacea) from Japan. Researches on Crustacea, 3: 39-51.

Sakai K., 1984 - Some thalassinideans (Decapoda: Crustacea) from Heron Is., Queensland, eastern Australia, and a new species of Gourretia from East Africa. The Beagle, Records of the Museums and Art Galleries of the Northern Territory, 1 (11): 95-108.

Sakai K., 1999 - Synopsis of the family Callianassidae, with keys to subfamilies, genera and species, and the description of new taxa (Crustacea: Decapoda: Thalassinidea). Zoologische Verhandelingen, 326: 1-152.

Schweitzer C. E, Feldmann R. M., Garassino A., Karasawa H. \& Schweigert G., 2010 - Systematic list of fossil decapod crustacean species. Crustaceana Monographs, 10: 1-222.

Sismonda E. 1846 - Descrizione dei Pesci e dei Crostacei fossili nel Piemonte. Memorie della Reale Accademia delle Scienze di Torino, ser. 2 (10): 1-89.

Sismonda E. 1861 - Appendice alla descrizione dei Pesci e dei Crostacei fossili nel Piemonte. Memorie della Reale Accademia delle Scienze di Torino, ser. 2 (19): 1-24.

Stimpson, W., 1859 - Notes on North America Crustacea in the Museum of the Smithsonian Institute, no. 1. Annals of the Lyceum of Natural History, 7: 49-93.

Swen K., Fraaije R. H. B. \& van der Zwaan G. J., 2001 Polymorphy and extinction of the Late Cretaceous burrowing shrimp Protocallianassa faujasi and first record of Corallianassa and Calliax (Crustacea, Decapoda, Thalassinoidea) from the Cretaceous. Contributions to Zoology, 70: 85-98.

Van Bakel B. W. M., Guinot D., Artal P., Fraaije R. H. B. \& Jagt J. W. M., 2012 - A revision of the Palaeocorystoidea and the phylogeny of raninoidian crabs (Crustacea, Decapoda, Brachyura, Podotremata). Zootaxa, 3215: 1-216.

Vazzana A., 2008 - Ranilia constricta (Milne Edwards, 1880) nel Tirreniano di Trumbacà vicino Reggio Calabria (Decapoda Brachyura Raninidae). Naturalista siciliano, ser. IV, 32 (3-4): 381-388.

Zariquiey Álvarez R., 1968 - Crustáceos decápodos ibéricos. Investigación Pesquera, 32: 1-510. 